2. Aristotle and Shields, C. (2016). De Anima. Oxford: Claredon Press [in English].

3. Athenaeus and Yonge, C. (1854). The Deipnosophists or Banquet of the Learned: in 3 volumes. London: Henry G. Bohn, vol. 3 [in English].

4. Descartes, R. (1650). The Passions of the Soule. Translated out of French into English. London: J. Martin and J. Ridley [in English].

5. Losev, A. F. (2000). Istoriya antichnoy estetiki [The history of antique aesthetics], vol. 2: Sofisty. Sokrat. Platon [Sophists. Socrates. Plato]. Moscow: AST; Kharkov: Folio [in Russian]

6. Plato and Cooper, J. (1997). Complete works. Indianapolis; Cambridge: Hackett Publishing Company [in English].

7. Rousseau, G. S. (2004). Nervous Acts: Essays on Literature, Culture and Sensibility. Basingstoke: Palgrave MacMillan [in English].

8. Shoja et al. (2016). History of the pineal gland. Child's Nervous System, vol. 32(4), pp. 583-586. Retrieved from: https://link.springer.com/ content/pdf/10.1007/s00381-015-2636-3.pdf [in English].

9. Tylor, E. B. (1920). Primitive culture: researches into the development of mythology, philosophy, religion, language, art, and custom: in 2 volumes, 6th ed. London: John Murray, vol. 2 [in English].

УДК 78.072 .2

DOI https://doi.org/10.31723/2524-0447-2019-29-2-14

Кирило Ігорович Чинчевий

ORCID: 0000-0003-0592-4037

аспірант кафедри теорії та історії музичного виконавства

Національної музичної академії України імені П. І. Чайковського

kirilltchinch@gmail.com

\title{
ФЕНОМЕН «МАЙСТЕР-КЛАС У МУЗИЧНОМУ МИСТЕЦТВІ: ПРОЛЕГОМЕНИ ДО ПОНЯТТЯ
}

Мета роботи полягає в історичному огляді феномена «майстер-клас» від його виникнення до сучасності. Методологія дослідження спирається на наукові культурологічні, філософсько-естетичні й музикознавчі праці, а також порівняльно-історичний, аналітичний $і$ діахронічний методи. Наукова новизна полягає в спробі виявити джерела й шляхи розвитку поняття «майстер-клас», систематизувати в історично-хронологічній послідовності відомості про феномен «майстер-клас» у музичному мистецтві й визначити місце феномена «майстер-клас» усучасномумузичномумистецтві. Висновки. Досліджено

(C) Чинчевий К. I., 2019 
джерела поняття «майстер-клас», починаючи від давньогрецького

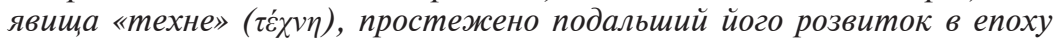
Відродження та бароко до становлення перших зразків сучасного вигляду «майстер-класу», які започаткував Ф. Ліст у XIX ст. У другій половині XX cm. явище майстер-класу набуває поширення не тільки як метод побудови уроку, а і як самостійна подія, що покликана розширити творчі й професійні горизонти учасників цього процесу (особливо в студентів). Також зроблено огляд російських фортепіанних шкіл початку XX ст., представники яких широко використовували у своїй педагогічній практиці форму «майстер-класу». Історичний огляд завершено аналізом використання форми «майстер-клас» у сучасних реаліях як одного з важливих складників навчального процесу престижних навчальних закладів світу та як незамінного засобу передачі досвіду, майстерності, навичок і вмінь між знаними майстрами фортепіанного мистецтва та їх менш досвідченими колегами в рамках одиничних майстер-класів чи серіях майстер-класів (так званих академіях) на численних конкурсах фортепіанного виконавства й фестивалях різних рівнів. Не оминули увагою й украӥнські заходи у форматі майстер-класів. Також визначено тлумачення поняття «майстер-клас» у різних тлумачних словниках і різноманітних мовних культурах: англійській, німецькій, франиузькій та інших.

Ключові слова: музичне виконавство, майстер-клас, техне, майстер.

Chinchevyi Kirill Ihorovych, Graduate Student at the Department of Theory and History of Musical Performance of the Ukrainian National Tchaikovsky Academy of Music

The phenomenon of "master class" in musical art: prolegomenon to the concept

The purpose of the work is a historical review of the phenomenon of "master class" from its occurrence to the present. The methodology of the research is based on scientific cultural, philosophical and aesthetic and musicological works, as well as comparative historical, analytical and diachronic methods. The scientific novelty of the research consists in an attempt to identify the origins and ways of developing the concept of a "master class", to systematize in a historical and chronological sequence information on the phenomenon of a "master class" in musical art and to determine the place of the phenomenon of a "master class" in modern musical art. Conclusions. The origins of the concept of a "master class", starting from the ancient Greek phenomenon "technete" ( $\tau \dot{\varepsilon} \chi v \eta)$, are investigated, its further development is traced in the Renaissance and Baroque to the formation of the first modern examples of a "master class" that arose in the creative and educational activities of F. Liszt in the 19th century. In the second half of the XX century, the phenomenon of master class is spreading not only as a method of constructing a lesson, but as an independent event, which is designed to expand the creative and professional horizons of participants in this process (especially students). A review is also made of Russian piano schools of the early twentieth century, 
whose representatives widely used the form of a "master class" in their teaching practice. The historical review is completed by the analysis of the use of the "master class" form in modern realities: as one of the important components of the educational process of prestigious educational institutions of the world and as an indispensable means of transferring experience, skills, abilities between famous masters of piano art and their less experienced colleagues within individual master classes or series of master classes (the so-called academies) in the framework of numerous piano competitions and festivals of various levels. Ukrainian events in the format of master classes were also not ignored. The interpretation of the concept of "master class" was also defined in various explanatory dictionaries and various language cultures: English, German, French and others.

Key words: musical performance, master class, technet, master.

Чинчевой Кирилл Игоревич, аспирант кафедры теории и истории музыкального исполнительства Национальной музыкальной академии Украины имени П. И. Чайковского.

Феномен «мастер-класс» в музыкальном искусстве: пролегомены к понятиям

Цель работы заключается в историческом обзоре феномена «мастер-класс» от его возникновения до современности. Методология исследования опирается на научные культурологические, философскоэстетические и музыковедческие труды, а такэе сравнительноисторический, аналитический и диахронический методы. Научная новизна заключается в попытке выявить истоки и пути развития понятия «мастер-класс», систематизировать в исторически-хронологической последовательности сведения о феномене «мастер-класс» в музыкальном искусстве и определить место феномена «мастер-класс» в современном музыкальном искусстве. Выводы. Исследованы истоки понятия «мастер-класс», начиная от древнегреческого явления «техне»

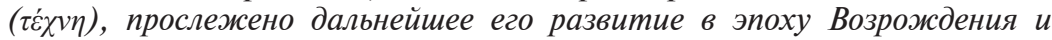
барокко до становления первых современных образиов «мастер-класса», которые возникли в творческо-педагогической деятельности Ф. Листа в XIX в. Во второй половине XX в. явление мастер-класса получает распространение не только как метода построения урока, но и как самостоятельного события, которое призвано расширить творческие и профессиональные горизонты участников этого процесса (особенно у студентов). Также сделан обзор российских фортепианных школ начала XX в., представители которых широко использовали в своей педагогической практике форму «мастер-класс». Исторический обзор завершен анализом использования формы «мастер-класс» в современных реалиях как одного из важных составляющих учебного процесса престижных учебных заведений мира и как незаменимого средства передачи опыта, мастерства, навыков и умений между известными мастерами фортепианного искусства и их менее опытными коллегами в рамках единичных мастер-классов или серий мастер-классов (так называемых академиях) на многочисленных конкурсах фортепианного 
исполнительства и фестивалях различных уровней. Не обошли вниманием и украинские мероприятия в формате мастер-классов. Также было определено толкование понятия «мастер-класс» в различных толковых словарях и различных языковых культурах: английской, немецкой, франиузской и других.

Ключевые слова: музыкальное исполнительство, мастер-класс, техне, мастер.

Aктуальність. Мистецтво є продуктом суто людської діяльності та набуває характеру людської пам'яті, досвіду та своєрідного генетичного коду. Треба також пам'ятати про гносеологічну функцію мистецтва. А якщо є освідомлення пізнавальної функції набутих навичок та знань суб'єктом, то має бути необхідність донести свій досвід до більш широкого загалу. Форм передачі цих знань та вмінь було декілька, серед яких і майстер-клас, що заслуговує більш детального розгляду. 3 часів виникнення явище майстер-класу відігравало важливу роль як спосіб комунікації та передачі досвіду. Поняття майстер-класу займає провідне місце і в наш час дуже широко використовується в різних сферах діяльності людини як трансляція культурного досвіду: педагогічного, наукового, мистецького тощо.

Викладення основного матеріалу. Перш ніж перейти, власне, до історії виникнення майстер-класу в музичній культурі, зупинимося на тлумаченні цього феномену в різних енциклопедичних словниках та різноманітних мовних культурах. Звернемо увагу на дві складові цього слова «майстер» і «клас», які походять від англійського «masterclass»: «master» - кращий в будь-якій галузі, людина, яка досягла високого мистецтва у своєї справі, а також прекрасно знає своє ремесло, наставник; а також «class» - заняття, урок.

Цікаво, що в багатьох європейських мовах тлумачення цього словосполучення збігається, однак із деякими особливостями. Близьким до англійського тлумачення $є$ німецьке трактування цієї дефініції: Meister - «майстер», «спеціаліст», «знавець»; Werkmeister - «майстер на виробництві», Kenner - «знавець». В італійській мові також присутня близькість: artigiano-«ремісник», «кустар», maestro - «майстер», «знавець», «спеціаліст».

Однак, у французькій та іспанській мовах, майстер-клас асоціюється з протилежністю самому майстру, буквально тлумачиться як той, що «навпроти майстра»: французька «contremaître» (старший) «майстер», «бригадир», «maître» «пан», «владика»; іспанська - «старший майстер», «начальник цеху».

Як бачимо, вже у самому словосполученні «майстер-клас» в різних мовних культурах закладено такі, на перший погляд, несумісні поняття 
як «ремісник», «знавець» (котре в контексті нашого дослідження $є$ близьким до поняття «епістема» знання, про що буде йти мова далі) та «майстер» (у самому високому значенні цього слова, близькому до Деміурга, Творця). Отже, поняття «майстер-клас» багатовимірне, мотивує до виникнення великої кількості визначень, котрі розкривають це явище з різних сторін.

Як не парадоксально може видаватися на перший погляд, ми вважаємо, що поняття «майстер-клас» бере свої певні витоки в такому давньогрецькому понятті як «техне» ( $\tau \dot{\varepsilon} \chi v \eta)$. Давні греки вкладали у це слово комплексний, всеосяжний зміст, дещо інший ніж той, який вкладається сьогодні у слово «техніка». Техне (від грец. $\tau \varepsilon \chi v \varepsilon$ [techne]) - мистецтво, майстерність, уміння - одна з базових характеристик давньогрецької культури. Відомий російський мислитель О. Лосєв вивчаючи етимологію слова «техне» підмічає, що у греків не було поділу на ремесло, мистецтво та науку, усі ці три компоненти вміщувало в себе поняття «техне» [6, с. 490]. Це широке поняття охоплює практично всі сфери людської діяльності та надзвичайно близьке до нашого розуміння поняття «майстер-клас», яке включає до себе і ремесло, і мистецтво, i науку. Розглянемо всі три компоненти більш детально.

Як вже було зазначено, в давньогрецькій традиції будь-яке майстерне виробництво розумілося як «техне», а тому для греків мистецтвом була не тільки праця архітектора або художника, але й праця теслі або ткача. Таким чином, поняттям «техне» позначалася будь яка людська праця (на противагу творінням природи), що є творчою, використовує вміння, а не лише натхнення й свідомо грунтується на правилах і канонах, а не тільки на досвіді. Греки були переконані, що вміння в мистецтві - досить істотна складова і тому ставилися до мистецтва, як до розумової діяльності. У своєму визначенні мистецтва вони наголошували на знанні, що є присутнім в мистецтві, і цінували мистецтво найбільше саме за це знання, а тому й наука, була не умоглядною, а практичною діяльністю.

Ремесло для греків було живим, таким, що мало душу (як і само мистецтво), сприймалося не тільки як людське, але й божественне, космологічне творіння, адже Космос розумівся як величніше «техне». Греки прагнули пояснити його будову за допомогою сакральних знань, котрі передавались від предків, а вміння застосовувати ці знання називали «техне».

Таким чином, у давніх греків не було поділу на високе, витончене мистецтво та на ремісничу працю, адже будь-яке людське творіння сприймалося як величніше космічне «техне», а тому й зрозуміло, чому давньогрецького майстра, ремісника, котрий зміг досягти досконалості 
у будь-якій справі називали деміургом (від давньогрецького $\delta \eta \mu-~$ оvрүós - «майстер, знавець, спеціаліст; ремісник, майстровий; світотворецьь, творець»; від давньогрецького $\delta \tilde{\eta} \mu о \varsigma$ - «земля, народ» + від давньогрецького е̌рүо - «справа, прачя, робота»). Якщо спочатку давні греки називали деміургом будь-яку людину, яка працює для людей (ремісника або посадову особу), то з часом так стали називати майстра, знавця своєї справи.

Відзначимо, що не у всіх грецьких філософів розуміння «техне» ідентичне. Так у Платона слово «техне» близьке до «епістеме» (від-

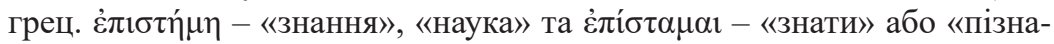
вати») - вміння орієнтуватись, розбиратись, що є близьким до сучасного слова «знання». Ще раз підкреслимо, що давні греки прагнули пояснювати світ і створення речей через науку та знання [8].

Відомий грецький філософ Аристотель у своїх працях також чимало уваги приділяє поняттю «техніка». Зокрема у творі «Нікомахова етика» [1] він вважає, що техніка - це розумна, творча поведінка, в основі якої правильне знання. Продовжуючи вчення Платона про буття, у своєму вченні про знання Аристотель робить безпосереднім предметом теорію науки. Науку і мистецтво Аристотель відокремлює від ремесла на тій підставі, що в їх основу покладено свідомий принцип і метод побудови, а ремесло він вважає лише результатом наслідування та звички. Відмінності між наукою і мистецтвом філософ віднаходить у тому, що наука має справу із сутнім, а мистецтво - зі становленням. Мистецтво $є$ виявом потенційного буття, «зарядженим» дійсністю, хоча й не є нею як такою.

Вже у XX ст. німецький мислитель М. Гайдеггер у своїх тлумаченнях про «техне» і «техніки» також відмічає близькість двох понять - «техне» і «епістеме». За його твердженнями вони обидва іменували знання в самому широкому сенсі. Гайдеггер стверджує, що на початку європейської історії в Давній Греції мистецтво називалося просто «техне», адже всі мистецтва корінилися не в мистецькій сфері, їх твори не були об'єктом естетичної насолоди. Розмірковуючи над тим, що таке техніка, німецький мислитель, спираючись на багатовіковий досвід філософії, припускає, що вона надається як засіб та наводить чотири аспекти його причинності. На думку мислителя, людина, що будує дім або корабель, або виковує жертовну чашу, виводить виготовлене 3 неявного відповідно таким чотирьом причинам: 1) causa materialis, матеріал, речовина, з котрої виготовляється, наприклад, срібна чаша; 2) causa formalis, форма, образ, який приймає цей матеріал; 3) causa finalis, мета, наприклад, жертвоприношення, яким визначається форма и матеріал необхідний длячаши; 4) causa efficiens - 
причина, що створює своєю дією готову реальну чашу, тобто срібних справ майстер. Отже, коли майстер створює будь-яку річ, він розкриває потаємне, що закладене у процесі ії створення. Він заздалегідь збирає образ і матеріал речі воєдино в світлі передбачуваної закінченості готової речі і намічає спосіб ії виготовлення. Саме тому В. Бібіхін, відомий російський перекладач М. Гайдеггера, тлумачить «техне» як вид «істинствування» (рос. истинствования), тобто явлення потаємної істини в результаті творення будь-якого мистецтва. Таким чином, вирішальна суть «техне» полягає зовсім не в операціях і маніпуляціях, не в застосуванні засобів, а в згаданому розкритті потаємного. Слід зазначити, що розкриття потаємного, істини, у кожному окремому випадку творення буде інакшим. Як пише Гайдеггер: «“Техне” розкриває те, що не саме себе виготовлює, а те, що ще не існує в наявності, а тому може вийти і виглядати і так, і інакше» [9, с. 225]. В якості такого розкриття, але не в якості виготовлення, «техне» і виявляється твором. Тому, спираючись на думки М. Гайдеггера, можна зробити висновок, що «техне» і є тим розкриттям таємниці, котрим просякнуті всі мистецтва.

Отже, «техне» для нас є тим поняттям, що безпосередньо пов'язано 3 мистецтвом, яким, у свою чергу є явище майстер-класу. Саме всі три складові давньогрецького «техне» - реміснича майстерність, високе мистецтво і наука - під час майстер-класу стають певним матеріалом для передачі майстром учневі умінь, знань, навичок та високої майстерності у широкому сенсі цього слова.

Майстер-клас як явище бере свій початок з глибини віків. До його прадавніх форм можна віднести методику викладання софістів у Давній Греції. Відомий дослідник античної культури Т. Гомперц у праці «Грецькі мислителі» пише: «Настав час, коли оригінальні й талановиті люди побажали самостійно заповнити цю прогалину освіти. З'явилися мандрівні вчителі, які подорожують з міста у місто; вони збирали навколо себе юнаків і навчали їх» [2, с. 442]. На цих уроках молодій людині викладались елементи позитивних наук, вчення натурфілософів, викладались та пояснювались поетичні твори, правила граматики, тонкощі метафізики. Цікавою особливістю цих уроків було те, що крім учня, 3 яким безпосередньо працював софіст, збиралась публіка, що виступала слухачем, сприймала інформацію, котру викладав майстер, переймала його досвід, вступала у полілог з іншими учасниками заходу.

Слід відзначити, що відношення до художників у широкому розумінні цього слова, зокрема, до музикантів як майстрів, почало змінюватися лише в епоху Відродження. Довгий час їх відносили до професій ремісників (як тесляр, муляр та ін.) і це було пов'язано, як зазначає О. Кривцун, з «новою якістю самосвідомості діячів мистецтва» 
[7, с. 61]. Практично всі науковці, котрі досліджують епоху Відродження, відзначають той факт, що майстерні художників стають центрами інтелектуального життя, в яких збиралися відомі філософи, вчені, аристократи. Можна сказати, що це були певні майстер-класи того часу, «з маргінальної фігури, - пише О. Кривцун, - якою був художник в середньовіччі, він потрапляє майже в сферу соціальної еліти» [там само]. Отже, саме 3 цього часу художник розуміється як титан, деміург, центр світобудови, носій універсальних здібностей.

Окремі елементи явища майстер-класу зустрічаються і в практиці концертуючих музикантів бароко. Відома італійська скрипалька, оперна співачка і композиторка Магдалена Лаура Сірмен отримувала освіту у Венеції в Ospedale dei Medicanti i брала уроки гри на скрипці у Джузепе Тартіні, відвідуючи його в Падуї. Судячи зі змісту листа Джузепе Тартіні, що дійшов до наших часів, в якому італійський музикант розповідає про прийоми гри на скрипці, можна припустити, що уроки, які прослідували згодом могли бути наближені за формою проведення до майстер - класу.

Людиною, котра започаткувала майстер-клас у його більш сучасних формах і проявах вважають Ф. Ліста. Відомий угорський піаніст почав викладати, ще у молодому віці у 1827 р. і продовжував майже до самої смерті (1886 р.). Про особливості занять Ф. Ліста ми дізнаємось із численних записів його учнів: Августа Гелеріха, Емі Фей, Карла Лахмунда та інших. Особливо цікавими та докладними $є$ нотатки Гелеpixa, котрий певний час був його секретарем. Саме від Гереліха нам стає відомо про винайдену Ф. Лістом форму проведення уроку, котрий за своїм змістом наближується до сучасного майстер-класу. Як зазначає Гелеріх у своїх спогадах [12], Ліст вважав такий вид занять найбільш корисним для інструменталістів, бо в ньому наявний елемент змагальності та творчого єднання. На таких заняттях завжди була присутня велика кількість учнів, кожний показував один або два твори. Основу репертуару складали твори самого майстра, також Ф. Шопена, Й. Брамса, А. Рубінштейна. На уроках Ф. Ліст не ставив перед учнями будь-яких особливих методичних завдань, більшою мірою розмірковував над втіленням образів, змістовним компонентом музики.

Елементи майстер-класу активно використовувались представниками російської фортепіанної школи починаючи з братів Рубінштейнів. Засновник Петербурзької консерваторії, відомий піаніст і композитор А. Рубінштейн під час своїх занять з учнями вимагав постійної присутності їх на заняттях своїх колег. Він контактував з аудиторією, розповідаючи тонкощі фортепіанного виконавства, ділився своїми поглядами на вирішення технічних та творчих задач, задавав запитання щодо виконання колег. Такої манери викладання дотримувався 
i його брат М. Рубінштейн. За згадками його учня Е. Зауера, учні, відвідуючи уроки колег: по-перше отримували можливість знайомитись 3 великою кількістю фортепіанного репертуару, по-друге виконання учнів носили характер концертних.

Інший яскравий представник російської фортепіанної школи, котрий також використовував елементи майстер-класу - К. Ігумнов. Як згадував один із учнів К. Ігумнова, відомий радянський музикознавець, піаніст і педагог Я. Мільштейн: «У класі зазвичай присутні майже всі учні, незалежно від того, чи грали вони в той день на уроці чи ні: вчилися не тільки граючи, але і слухаючи інших. Навіть у найбільш інертних учнів народжувалося ні з чим не порівнянне відчуття виконавської співтворчості, живого участі в творення музики, зосередженого і побожного ставлення до мистецтва» [9, с. 398].

Ще один із представників російської фортепіанної школи Г. Нейгауз продовжує традиції проведення або використання елементів майстер-класу на своїх заняттях. Як згадує учень Нейгауза I. Жуков: «Під час гри на уроці <..> в класі, як це майже традиційно бувало, повно людей, і не тільки його студентів» [6, с. 40]. Для Г. Нейгауза було важливим комунікувати 3 аудиторією, ділитись своїми враженнями щодо виконання, ставити запитання учням.

У другій половині XX столітті явище майстер-класу набуває поширення не тільки як метод побудови уроку, а як самостійна подія, що покликана розширити творчі та професійні горизонти учасників цього процесу (особливо у студентів). Багато відомих митців, зокрема піаністів дають майстер-класи. Серед яких, наприклад, голландський клавесиніст, органіст, диригент, музикознавець та педагог Г. Леонхардт. У консерваторії ім. Я. П. Свелінка в Амстердамі з 1954 по 1988 р.p. регулярно проводив майстер-класи. Деякі з них дійшли до нас у відеозаписах. Утворюються «літні академії», самостійні цикли майстер-класів при музичних закладах (консерваторіях, вищих школах музики) або ж при фестивалях, де один чи одразу декілька відомих майстрів охоче діляться своїм професійним досвідом.

Практично на базі усіх найвідоміших фестивалів академічної музики створюються академії з майстер-класами: у Верб'є з 1994 року (Verbier Festival Academy); майстер класи у рамках фестивалю ВВС Proms, академія на базі люцернського фестивалю (Lucerne Festival Academy); майстер-класи на базі Срусалимського музичного центру (The Jerusalem Music Centre), Міжнародна академія у Ліхтенштейні (Internationale Musik akademie in Liechtenstein) та інші.

31998 року, на базі Міжнародного конкурсу молодих піаністів пам'яті Володимира Горовиця, у Києві започатковано «Школу 
виконавської майстерності» - майстер-класи провідних світових музикантів серед яких Уорен Томпсон, Володимир Крайнєв, Норма Фішер, Діна Іоффе, Адам Вібровські, Яков Касман, а також відомі українські музиканти - Ігор Рябов, Валерій Козлов, Борис Архімович, Юрій Кот. У 2000 році «Школа виконавської майстерності» переросла у Міжнародну «Літню музичну академію». Формат проведення цього заходу передбачає декілька майстер-класів 3 майстром для учасника, а за підсумками проводиться виступ учасника на концерті, навіть із супроводом оркестру. Ідею київської «Літньої музичної академії» підхопив i Чернігів, у якому на базі чернігівського обласного філармонійного центру фестивалів та концертних програм уже багато років поспіль проходить подібний захід.

Багато передових музичних закладів вводять майстер-клас до системи своєї освіти, як важливу складову творчого і професійного зростання своїх учнів, серед яких найвизначніші і відомі, що постійно проводять майстер-класи із залученням найкращих музикантів світу: Королівська академія музики (Royal Academy of Music) та Королівський коледж музики (Royal College of Music) у Лондоні, Джульярдська школа музики (Juilliard School), міжнародна літня академія у консерваторії Зальцбурга (Universität Mozarteum Salzburg), Піаністична академія у Імолі (Accademia Pianistica Imola), Міжнародна музична академія ім. А. Рубінштейна у Дюссельдорфі (The Anton Rubinstein International Music Academy).

Учасниками таких заходів $€$ як студенти вищеназваних установ, так і музиканти з усього світу. Для багатьох навчальних закладів проведення майстер-класів та літніх академій - це один з методів самопрезентації навчального закладу та його викладачів. Відвідавши, або взявши участь у таких заходах потенційний студент може зробити остаточний вибір щодо майбутнього навчання, ознайомитись 3 методами викладання, обрати педагога, відчути загальну атмосферу музичного закладу. Підтримує світові тенденції й пострадянський музично-освітній простір. Зокрема московська державна консерваторія постійно проводить майстер-класи та літні академії у своєму закладі, залучаючи провідних музикантів світу.

Висновок. Підсумовуючи вищесказане варто зазначити, що «майстер-клас» - один 3 важливих феноменів культури загалом i музичної культури зокрема. Як і багато інших явищ європейської культури майстер-клас виник завдячуючи античній культурі і активно був використаний в епоху Відродження. Починаючи з ХІХстоліття він здобув сучасні риси завдячуючи Ф. Лісту, пройшовши крізь віки він не втратив своєї актуальності в наш час. Майстер-клас як засіб передачі 
ремесла, мистецтва і науки широко використовується у світовій культурній практиці. Саме формат майстер-класу обрано як ключовий для обміну досвідом між митцями в рамках багатьох конкурсів, академій. Майстер-клас має великий потенціал у сучасній культурі для розвитку і ще більш широкого використання, зокрема у контексті інформаційних технологій.

\section{СПИСОК ЛІТЕРАТУРИ}

1. Азимов Э.Г., Щукин А.Н. Новый словарь методических терминов и понятий. Москва : ИКАР, 2009. 448 с.

2. Арістотель. Нікомахова етика. Київ : Аквілон-Плюс, 2002. 480 c. URL: http://www.ae-lib.org.ua/texts/aristoteles_nicomachean ethics_ua.htm. (дата звернення: 03.10.2019).

3. Гомперц Т. Греческие мыслители. Санкт-Петербург : Алетейя, 1999. $606+272 \mathrm{c}$.

4. Грохотов С.В. Уроки Гольденвейзера. Москва : Классика-ХХІ, 2000. 248 c.

5. Ефремова Т.Ф. Новый словарь русского языка. Толково-словообразовательный. Москва : Русский язык, 2000. 2310 c. URL: http:// gufo.me/dict/efremova/мастер-класс. (дата звернення: 10.09.2019).

6. Жуков И.М. Уроки жизни (о Г.Г. Нейгаузе). Москва : Музыкальная академия, 2007. № 1. С. 39-45.

7. Кривцун О.А. Эстетика : учебник. Москва : Аспект Пресс, 2000. $434 \mathrm{c}$.

8. Лосев А.Ф. 12 тезисов об античной культуре. URL: http://psylib.org.ua/books/_losew02.htm (дата звернення: 17.11.2019).

9. Мильштейн Я.И. Константин Николаевич Игумнов. Москва : Музыка, 1975. 471с.

10. Платон. Собрание сочинений : в 4 т. ; Российская академия наук, институт философии. Москва : Мысль, 1994. Том 4. 830 с.

11. Хайдеггер М. Время и бытие : статьи и выступления. Москва : Республика, 1993. 447 с.

12. Jerger W. The Piano Master Classes of Franz Liszt, 1884-1886: Diary Notes of August Gцllerich. Bloomington : Indiana University Press, 2010. 224 p.

\section{REFERENCES}

1. Azimov, E. G., Shchukin A. N. (2009) Novyy slovar metodicheskikh terminov i ponyatiy. Moskva: IKAR [in Russian].

2. Aristotel (2002) Nikomakhova etika. Kiï: Akvilon-Plyus. URL: http://www.ae-lib.org.ua/texts/aristoteles_nicomachean_ethics ua.htm. (data zvernennya: 10.09.2019). [in Ukrainian]

3. Gomperts, T. (1999) Grecheskie mysliteli. Sankt-Peterburg: Aleteyya. [in Russian].

4. Grokhotov, S.V. (2000) Uroki Goldenveyzera. Moskva: KlassikaXXI. [in Russian]. 
5. Yefremova, T. F. (2000) Novyy slovar russkogo yazyka. Tolkovoslovoobrazovatelnyy. Moskva: Russkiy yazyk URL: http://gufo.me/dict/ efremova/master-klass. (data zvernennya: 10.09.2019). [in Russian].

6. Zhukov, I. M. (2007) Uroki zhizni (o G.G. Neygauze). Moskva: Muzykalnaya akademiya. №1. S. 39 - 45. [in Russian].

7. Krivtsun, O.A. (2000) Estetika: Uchebnik. Moskva: Aspekt Press. [in Russian].

8. Losev, A. F. 12 tezisov ob antichnoy kulture. URL: http://psylib. org.ua/books/_losew02.htm (data zvernennya: 17.11.2019). [in Russian].

9. Milshteyn, Ya. I. (1975) Konstantin Nikolaevich Igumnov. Moskva: Muzyka [in Russian].

10. Platon (1994) Sobranie sochineniy v 4 t. / Rossiyskaya akademiya nauk, institut filosofii. Moskva: Mysl. Tom 4. [in Russian].

11. Khaydegger, M. (1993) Vremya i bytie: Stati i vystupleniya. Moskva: Respublika. [in Russian].

12. Jerger, W. (2010) The Piano Master Classes of Franz Liszt, 1884 1886: Diary Notes of August Gцllerich. Bloomington: Indiana University Press [in English].

UDC $78.03+782.1 / 784.95$

DOI https://doi.org/10.31723/2524-0447-2019-29-2-15

Wang Na

ORCID: 0000-0001-6014-1604

Applicant at the Department of Music History and Musical Ethnography

Odessa National A. V. Nezhdanova Academy of Music

WangnaOd19@gmail.com

\section{MODERN OPERA HOUSE AS A SUBJECT OF MUSICOLOGIST STUDIES: MUSICAL, HISTORICAL AND INTERPRETATION ASPECTS}

The aim of the article is to identify the fundamental principles, artistic parameters and value-semantic guidelines of the modern opera house, considered in a wide musicological discursive field. To study the socio-aesthetic role of artistic value, theoretical parameters for considering the relationship and mutual influence of the phenomena of theater and opera are formed. The methodology of the work is determined by a system of historical and theoretical approaches, each of which is represented by a complex of methods based on the combination of such methodological approaches as musical and historical, interpretive, opera

(C) Wang Na, 2019 